\title{
Productivity Enhancement in a Cattle-Coconut Integrated System- Implications for Environmental Sustainability
}

\author{
Seresinhe T, Sujani IWAS \\ Department of Animal Science, Faculty of Agriculture, University of Ruhuna \\ Mapalana, Kamburupitiya 81100, Sri Lanka \\ thakshas@ansci.ruh.ac.lk; tseresinhe@gmail.com
}

\begin{abstract}
A three year grazing study was conducted with cross bred heifers fed on natural herbage, tree fodder, rice straw and supplements. The treatments were coconut monoculture stand without animal component (control T1), coconut monoculture stand without animal component but with standard fertilizer levels and other management practices (T2), heifers grazing natural herbage under coconut (T3) and cattle fed with natural grasses + plus tree fodder and supplements (T4). Results revealed that, provision of tree fodder and supplements significantly improved the cattle performance by means of reducing ageand higher live weights at first calving. The birth weights of calves and milk yields of dams were also increased $(\mathrm{P}<0.05)$ with supplementation. Treatments $\mathrm{T} 3$ and T4 significantly enhanced the nut yield per palm and copra production per palm. A near doubling of coconut yield was reported in grazed coconut plots when compared with un-grazed coconut plots. There was no significant change in water holding capacity in response to the treatments. No changes were observed either in N, P, and K content in soil or coconut leaf due to treatments. Conclusion can be drawn as that integrated system improved the productivity in both animal and crop components.
\end{abstract}

Key Words: Cross-Bred Cattle, Integration, Natural Herbage,Supplements, Tree Fodder

\section{INTRODUCTION}

Considering the low productivity and poor returns from existing monoculture coconut plantations in Sri Lanka, there is a critical need to maximize the use of land. A shift from monoculture system to integration system has become a national priority to satisfy the growing demand for food and other supplies due to rapidly increasing population and urbanization. Since the new land for further expansion of coconut culture is very limited, increasing the productivity of existing coconut plantations would be the most appropriate development strategy. Despite the agronomic feasibility and economic viability of integration with livestock in coconut holdings, the full potential of this beneficial system of land use has not been realized largely due to lack of information and knowledge. In many instances cattle are seen grazing under the coconut trees. Here it is often the case that the owners of the coconut trees are not the owners of the cattle. Cattle are owned by small poor farmers and usually the owner of the coconut trees lets them graze at no cost. Being an environmental friendly approach, coconut based livestock integration practices can make significant contribution to the conservation of ecological base of farming (Manyong et al. 2006; Nandasaba et al. 2006).

Therefore, objective of the present study was to disclose the effect of coconut cattle integration with better use of supplements for cattle on the performance of cross bred cattle as well as coconut yield parameters and soil parameters.

\section{MATERIAL AND METHODS}

A three year experiment was conducted in a marginal coconut plantation situated in a farming village in the Southern Sri Lanka to study the performance of a coconut cattle 
integrated system and its sustainability. The coconut plantation is nearly 40 years old with ordinary tall variety and planted at $8 \times 8 \mathrm{~m}$ square system with a density of $156 \mathrm{palms} / \mathrm{ha}$. The light transmission by the canopy was $45 \%$, as measured periodically using a LUX meter. That means the palms in the plantation are still remaining in the economical productive state. But unfortunately the land has been neglected for more than a decade; with a poor production capacity.

\section{Treatments and design}

A Randomized Complete Block Design (RCBD) with three replicates depending on the terrain of the land and live weight of animals was used. Land and animals were blocked, with each block consisting of four experimental units which were uniform as far as possible within blocks. There were 12 experimental units each having a land area of 0.4 ha $(1$ acre). The grazing land under coconuts was natural herbage, considered as weeds by the owners of coconut plantations in which landless farmers traditionally tethered their cattle for grazing under coconut palms.

The treatments were as follows: T1. Control-coconut monoculture stand (without animal component); T2. Coconut monoculture stand with standard fertilizer levels and other management practices as recommended by the CRI (without animal component); T3. Cattle fed with natural grasses, simulates the grazing system adopted by local farmers in coconut plantations; and T4. Cattle fed with natural grasses + tree fodder + low cost concentrates + minerals to show how this system could be improved by the use of locally available low cost supplements.

Twelve cross-bred heifers $(140 \pm 4 \mathrm{~kg})$ which have been purchased from small farmers, representing the cattle population of the area. The calves that were born were kept with their dams in the paddocks for two weeks and removed thereafter to maintain the same grazing pressure. Calves were brought to the dams at milking time to stimulate milk let down.

Heifers were tethered on selected coconut palms in the plots using nylon ropes. 22 palms were allocated for each heifer. The length of the tethered rope during the day time was $4 \mathrm{~m}$ allowing it to graze an area with a radius of $4 \mathrm{~m}$, while it was reduced to $2 \mathrm{~m}$ during the night (from 5.00 p.m. to 8.00 a.m.). This procedure was carried out to incorporate more dung and urine to the manure circle of the coconut palm. Ad libitum drinking water was provided for the animals during both day and night.

\section{Feeding of rice straw and supplements}

Two percent of urea treated rice straw ( $2 \mathrm{~kg}$ of urea was mixed in $100 \mathrm{l}$ of water for $100 \mathrm{~kg}$ of straw) was given to the animals in both treatments only during the dry period to compensate the reduction of herbage. Tree fodder $(4 \mathrm{~kg}$ of fresh Gliricidia/head/day) and concentrate supplement $(250 \mathrm{~g} / \mathrm{head} /$ day $)$ were provided only to the group of supplemented animals (T4). The concentrate supplement composed urea, molasses, rice polishing and vitamin-mineral mixture. The feed intake (except grazing herbage) and water intake of every animal was measured once a week.

\section{Data collection and analyses}

Live weights were recorded monthly. In addition to normal observations and records on oestrus, conception, calving, and lactation were kept. Coconuts were harvested by monthly to record nut and copra yields. 
Soil and leaf samples were taken once a year (two times during the period of experiment). The soil samples were taken within the manure circles of selected palms using the top soil (0-10 $\mathrm{cm}$ depth) and the leaf samples were taken from the $14^{\text {th }}$ leaf of the palm. Coconut and soil $\mathrm{N}$ and $\mathrm{P}$ contents were determined using standard procedures. Data were ananlyzed by analysis of varience (ANOVA) using Generalized Linear Model procedure Version 6 SAS system for windows. When ANOVA showed significant treatment effects $(\mathrm{P}<0.05)$, mean comparison was done using the Duncan multiple range test.

\section{RESULTS AND DISCUSSION}

With the effect of treatment, T4 where cattle were supplemented with tree fodder, low cost concentrate and minerals reported significantly enhanced average body weight at calving and it is nearly a $10 \%$ improvement when compared with T3. In a same manner T4 significantly reduced the age at calving from 46 to 38 months which is about $17 \%$ reduction. Average birth weight of calves was significantly increased from 13.5 to 15.25 $\mathrm{kg}$ and it was recorded to be nearly a $13 \%$ increment. A $47 \%$ increment was observed in daily milk yield rising from 2.35 to $3.46 \mathrm{~kg}$. Seresinhe \& Pathirana (2008) reported that supplementation of low inputs such as tree fodder and concentrate supplemnt could enhance the crude protein content of feed consumes as well as nutrient intake and digestibility by significant levels resulted better performance of cattle.

Highest nut yield and copra yield per palm were recorded with T4 and follwed by T3, $\mathrm{T} 2$, and T1. Nut yield in T4 and T3 was closely similar and same story repeated in T2 and T1. Copra yield in T4, T3, and T2 was reported to be very much similar and value almost doubled when campared with T1. Either treatment was failed to improve water holding capacity of soil compared to the T1, the control. No significant diference was observed either in NPK content in soil or coconut leaf.

Table 1. Effect of treatments on body weight at calving, age at calving and milk yield of female cattle

\begin{tabular}{lcccc}
\hline \hline Treatments & $\begin{array}{c}\text { Body weight at } \\
\text { calving (kg) }\end{array}$ & $\begin{array}{c}\text { Age at calving } \\
\text { (months) }\end{array}$ & $\begin{array}{c}\text { Average birth weight } \\
\text { of calves }(\mathrm{kg})\end{array}$ & Milk yield kg/d \\
\hline T1* & - & - & - & - \\
T2* & - & - & - & - \\
T3 & $185.90^{\mathrm{b}} \pm 4.44$ & $46^{\mathrm{b}} \pm 2.1$ & $13.50^{\mathrm{b}}$ & $2.35^{\mathrm{b}} \pm 0.13$ \\
$\mathrm{~T} 4$ & $203.17^{\mathrm{a}} \pm 4.71$ & $38^{\mathrm{a}} \pm 1.9$ & $15.25^{\mathrm{a}}$ & $3.46^{\mathrm{a}} \pm 0.19$ \\
\hline
\end{tabular}

*No animal component in T1 and T2; Values with different superscripts within same column are significantly different at $\mathrm{P}<0.05$

Closely matched initial live weights at the beginning of the experiment differed significantly at calving. Although the feeding of tree fodder and concentrate supplement tended to reduce the age at calving as well. The daily milk yield of $\mathrm{T} 4$ group of animals were higher $(\mathrm{P}<0.05)$ with supplementation. In this study birth weight was a good predictor of the potential milk yield of dam since there was a high correlation with supplemented animals between the two parameters $\left(r^{2}=0.89\right)$.

Just grazing (T3) increased coconut yield by about 30\%. No wonder the owners of the coconut trees were quite happy for the small farmers' animals to graze under them. The increase in number of coconut nuts probably due to the recycling of precious organic 
manure wastes might have been responsible for conserving ecosystem and thus increasing the fertility of soil (Anis et al. 2015).

Table 2. Effect of treatments on yield of nuts and copra per palm and soil water holding capacity

\begin{tabular}{lccc}
\hline \hline Treatments & Nuts/palm & Copra/palm $(\mathrm{kg})$ & Water holding capacity $(\mathrm{mm} / \mathrm{m})$ \\
\hline T1 & $17.6^{\mathrm{c}} \pm 1.54$ & $4.65^{\mathrm{b}} \pm 0.89$ & $11.21 \pm 0.78$ \\
$\mathrm{~T} 2$ & $21.8^{\mathrm{bc}} \pm 1.23$ & $8.78^{\mathrm{ab}} \pm 0.99$ & $12.44 \pm 0.88$ \\
$\mathrm{~T} 3$ & $30.4^{\mathrm{ab}} \pm 1.43$ & $9.12^{\mathrm{a}} \pm 1.01$ & $13.74 \pm 0.67$ \\
$\mathrm{~T} 4$ & $32.2^{\mathrm{a}} \pm 1.34$ & $9.66^{\mathrm{a}} \pm 1.11$ & $13.89 \pm 0.66$ \\
\hline
\end{tabular}

Values with different superscripts within same column are significantly different at $\mathrm{P}<0.05$

This was no doubt due to a rapid turn over of biomass and the effect on soil quality seen here as water holding capacity. Bringing nutrients for the cattle from outside further increased coconut and copra yield not doubt as a result of the $\mathrm{N}, \mathrm{P}$, and $\mathrm{K}$ contained in the feed. This can also be seen in Table 3 showing an increase in $\mathrm{N}, \mathrm{P}$, and $\mathrm{K}$ when feed from outside was added.

Table 3. Effect of treatments on N, P, and $\mathrm{K}$ content in soil and coconut leaf

\begin{tabular}{lccccccc}
\hline \hline \multirow{2}{*}{ Treatment } & \multicolumn{3}{c}{ Content in soil (\%) } & & \multicolumn{3}{c}{ Content in coconut leaf (\%) } \\
\cline { 2 - 4 } \cline { 6 - 8 } T1 & $\mathrm{N}$ & $\mathrm{P}$ & $\mathrm{K}$ & & $\mathrm{N}$ & $\mathrm{P}$ & $\mathrm{K}$ \\
\cline { 2 - 4 } $\mathrm{T} 2$ & $2.01 \pm 0.32$ & $0.14 \pm 0.001$ & $0.87 \pm 0.01$ & & $0.84 \pm 0.01$ & $0.05 \pm 0.004$ & $0.022 \pm 0.001$ \\
$\mathrm{~T} 3$ & $2.00 \pm 0.32$ & $0.15 \pm 0.001$ & $1.0 \pm 0.05$ & & $0.86 \pm 0.05$ & $0.069 \pm 0.003$ & $0.03 \pm 0.002$ \\
$\mathrm{~T} 4$ & $1.94 \pm 0.09$ & $0.15 \pm 0.002$ & $0.99 \pm 0.04$ & & $0.96 \pm 0.04$ & $0.032 \pm 0.005$ & $0.019 \pm 0.001$ \\
& $2.05 \pm 0.11$ & $0.15 \pm 0.003$ & $1.18 \pm 0.99$ & & $1.004 \pm 0.06$ & $0.028 \pm 0.002$ & $0.024 \pm 0.001$ \\
\hline
\end{tabular}

Values with different superscripts within same column are significantly different at $\mathrm{P}<0.05$

\section{Environmental sustainbility}

Integration of pasture and cattle in coconut plantation is expected to increase the value of the land productivity.This may be due to efficient nutrient recycling. The manure produced could be recycled directly as fertilizer.In addition to the direct contribution of plant nutrients, manure provided important organic matter to the soil, maintaining its structure, water retention and drainage capacity. The integration of livestock to utilize the vegetative ground cover under the tree canopy has been shown to increase overall production and save up to $40 \%$ of the cost of weed control as well as suppressed the cost of herbicides, reducing the cost of weed control and provided an additional income from milk production. This system also safeguarded the environment and avoid chemical pollution while adding organic matter to the soil. Ramrao et al. (2006) reported that livestock became an integral part of farming system as such, better utilization of land, water, input and output resources in this mixed farming model with cows, as compared to arable farming alone. Similarly, Sibbald et al.(2001) showed that productivity of sheep grazing under trees was similar and in dry years greater than sheep grazing a similar area in open land. Evidently the growth of the trees was a bonus and soil fertility undoubtedly improved.

Pontesi et al. (2014) showed that the presence of trees tended to reduce methane emissions by cattle in integrated crop-livestock systems. Directly through a reduction in $\mathrm{CH}_{4}$ per unit of animal product resulting from the increase in feed quality and animal 
welfare (i.e. improved environmental temperature for ICLSs with trees), and indirectly through reduction of area subjected to land use changes (i.e. leading to loss of soil $\mathrm{C}$ stocks). Although the present study has not measured or estimated the emission intensity it can be converse relating to the other improved parameters of the system. Since the reduction of emission intensity of livestock production is addressed through dietary management to reduce enteric fermentation (feed supplements and management), herd management (productivity and reproduction parameters) and manure management, through these parameters, the emission intensity can be inferred. As indicated by the results, improved live weights in heifers with improved reproductive performance (calves of higher live weight at birth), higher milk yield witnessed the significantly improved productivity and reproduction parameters. Addressing the optimum utilization and better management of manure, the substitution of chemical fertilizer by dung and urine has improved plant nutrient status and soil fertility status. As dung and urine remain largely aerobic the production of greenhouse gases are minimized. Considering above all key points, it can be hypothesized that integrated system of coconut and livestock is a possible solution to reduce emission intensity.

\section{CONCLUSION}

Conclusion can be drawn as that coconut cattle integrated system improved the productivity in both animal and crop components through better utilization of land, water, input, and output resources in this mixed farming model with cows.

\section{REFERENCES}

Anis SD, Kaligis DA, Pangemanan SP. 2015. Integration of cattle and koronivia grass pasture underneath mature coconuts in North Sulawesi, Indonesia Integration of cattle and koronivia grass pasture underneath mature coconuts in North Sulawesi, Indonesia. Livest Res Rural Develop. 27:2015.

Manyong VM, Okike I, Williams TO. 2006. Effective dimensionality and factors affecting crop-livestock integration of West African savannas: A combination of principal component analysis and Tobit approaches. Agric Econ. 35:145-155.

Nandasaba J, Muyekho FN, Wanyama JM, Miriti J, Ndung K, Lusweti CM, Nyambati IE, Mmwangi T, Cheruiyot DT, Kamau JN, Kabirizi J. 2006. Study on potential crop livestock integration and nutrient management in farming systems in West Kenya. In: Responding to Chellenges and Opportunities Through Innovative Agricultural Technologies, Knowledge and Approaches. Proceedings of the $10^{\text {th }}$ KARI Biennial Scientific Conference and 2 $2^{\text {nd }}$ Agricultural Forum. Nairobi, 18 November 2006. Nairobi (Kenya): Kenya Agricultural Research Institute. p. 1-4.

Pontesi LD, Raquesl S, Edemar SB, De F, Vanderley C, Da PS, Ian MC, Alexandre B, Cimelio B, Carvalho PC, De F. 2014. Methane emissions from ruminants in integrated crop-livestock systems. Trop Grasslands. 2:124-126.

Ramrao WJ, Tiwari SP, Singh P. 2006. Crop-livestock integrated farming system for the marginal farmers in rain fed regions of Chhattisgarh in Central India. Livest Res Rural Develop. 18:2006.

Seresinhe T, Pathirana KK. 2008.Effect of supplementation of straw based diets on the digestibility and microbial nitrogen production of cross bred cattle. World J Agric Sci. 4:745-751.

Sibbald AR, Eason WR, McAdam JH, Hislop AM. 2001. The establishment phase of a silvopastoral network experiment in the UK. Agrofor Syst. 39:39-53. 